\title{
IMPLEMENTASI KEBIJAKAN PENGEMBANGAN KAWASAN STRATEGIS CEPAT TUMBUH (KSCT) DI KABUPATEN PACITAN
}

\author{
Santi Endah Lestari \\ Program Studi Magister Ilmu Administrasi Publik, Fakultas Ilmu Administrasi, Universitas Brawijaya \\ .(santi.endah85@gmail.com) \\ Agus Suryono dan Tjahjanulin Domai \\ Program Studi Magister Ilmu Administrasi Publik, Fakultas Ilmu Administrasi, Universitas Brawijaya
}

\begin{abstract}
Abstrak
Latar belakang dilakukannya penelitian ini adalah masih terjadinya kesenjangan kesejahteraan antara masyarakat yang tinggal di daerah pegunungan (wilayah bagian utara) dan masyarakat yang tinggal di daerah pesisir (wilayah bagian selatan). Kesenjangan ini ditunjukkan dengan lebih tingginya jumlah penduduk miskin yang ada di kawasan agropolitan daripada jumlah penduduk miskin yang ada di kawasan pariwisata. Disamping itu jumlah industri di kawasan pariwisata lebih banyak dibandingkan kawasan agropolitan.Selanjutnya tujuan melakukan penelitian ini adalah untuk mengetahui hasil kebijakan Kawasan Strategis Cepat Tumbuh (KSCT) di Kabupaten Pacitan. Metode yang digunakan adalah kualitatif dengan dengan pendekatan model proses implementasi kebijakan Grindle (1980) dan model interaktif Miles, Huberman dan Saldana (2014) yang digunakan untuk menganalisa data dan menampilkan keseluruhan fenomena yang ada. Sedangkan teknik pengumpulan data didapatkan dari hasil wawancara dengan informan, studi dokumen, dan observasi. Hasil dari impementasi kebijakan KSCT tersebu ternyata telah berhasil memberikan dampak positf kepada pengembangan kawasan cepat tumbuh yang ada di wilayah selatan (daerah pariwisata pantai). Sedangkan di daerah agropolitan (utara) hasil kebijkaan KSCT belum dilaksanakan dan belum memberikan dampak terhadap pengembangan kawasan agropolitan.
\end{abstract}

Kata Kunci: kebijakan, kawasan strategis

\begin{abstract}
Background of this research is the data founded shows disparity between north area as agroplolitan area and south area as socio cultural or tourism area. This disparity appears on poverty number in agropolitan area (north) higher than poverty number in tourism area (south). The industry number data, however, is also seen much higher in tourism area. This research is a study case and will discuss about the implementation process of policy of strategic area development in Kabupaten Pacitan. Therefore, the problems can be concluded into: How the implementation outcomes are achieved in Kabupaten Pacitan. Those, subjectives of this research are determined to understand and exhibit the KSCT implementation outcomes. The methode is using qualitatif approach with Grindle (1980) implementation model. Interactive model of Miles Huberman. And Saldana is also apllied for analysing and explaining the otucomes of implementation phenomenon. While for data collecting, some depth intreviews, document observations are elaborated to fulfil the data requirements. The result of this research is the implementation has given the positive outcomes just for south area (tourism area). While the outcomes of this KSCT implementation in the north has not been accepted by people in the agropolitan area
\end{abstract}

Keywords: policy, strategic area

\section{PENDAHULUAN}

Nugroho (2017: 537) menyampaikan bahwa model proses kebijakan yang paling klasik adalah model Easton yang menyatakan bahwa kebijakan adalah output dari sistem (politik) yang terdiri dari input, throughput, dan output. Input yang dimaksud adalah tuntutan dan dukungan, throughput adalah sistem politis dan output adalah kebijakan. Beberapa akademis mulai mengembangkan model proses implementasi dari Easton tersebut. Beberapa model proses implementasi tersebut ada yang bersifat liner diantaranya model Andersen dan Model Dye. Model Andersen menyebutkan bahwa proses implementasi dimulai dari policy agenda, policy 
formulation, policy adoption, policy implementation dan policy evaluation. Sedangkan dari model proses implementasi Dye diawali dari (1) Identification of policy problem, (2) Agenda Setting (3) Policy Formulation, (4) Policy Legitimation (5) Policy Implementation dan (6) Policy Evaluation.

Kebijakan publik yang telah disyahkan oleh kekuatan hukum yang selanjutnya dilaksanakan oleh implementor, seringkali menimbulkan konflik yang dapat mempengaruhi pelaksanaan kebijakan dan keberlangsungan kebijakan. Selain itu kebijakan yang membingungkan juga dapat dijadikan alasan implementor untuk tidak melaksanakan kebijakan tersebut "Unclear or confusing policy objectives or actions may be one reason why some policies are not implemented" ( Ketidakjelasan dan tujuan atau kebijakan yang membingungkan merupakan kemungkinan penyebab kenapa beberapa kebijakan tidak dijalankan) (Calista 1994:32)1 dalam jurnal (Mthethwa, 2012).

Sedangkan Grindle (1980) mengemukakan bahwa implementasi ditentukan oleh dua hal yaitu isi kebijakan (content of policy) dan lingkungan implementasi (context of implementation). Isi kebijakan (content of policy) mencakup (1) sejauh mana isi kebijakan memuat kepentingan kelompok sasaran atau target groups (2) jenis manfaat yang diterima oleh target group; (3) sejauh mana perubahan diinginkan dari sebuah kebijakan; (4) Kedudukan pembuat kebijakan; (5) Pelaksana program; (6) Sumber daya yang dikerahkan. Sedangkan context of implementation menurut Grindle memuat (1) kekuasaan, kepentingan, dan strategi aktor yang terlibat; (2) Karakteristik lembaga dan penguasa; (3) Kepatuhan dan daya tanggap.

Keterlibatan pusat dalam penentuan strategi di daerah tampak dari berbagai macam peraturan-peraturan kebijakan pusat. Kebijakan yang bersifat top down tersebut seharusnya dapat dipahami oleh pelaksana kebijakan di daerah, begitu juga dengan tujuan yang terdapat dalam isi kebijakan yang harusnya secara jelas menjabarkan tentang perihal apa saja yang harus dipenuhi untuk mencapai tujuan yang dimaksud tersebut. Namun kebijakan-kebijakan top down tersebut sebagian besar masih bersifat umum, sehingga para birokrat di daerah sering mengambil tindakan diskresi pada pelaksanaannya dimana kebijakan top down tersebut tidak sesuai atau tidak mencakup permasalahan-permasalahn di lapangan (Ali, 2006:52).

Gambaran umum suatu masyarakat dikatakan makmur dan sejahtera adalah apabila minimal mereka sanggup memenuhi kebutuhan dasarnya yang tidak hanya

\footnotetext{
${ }^{1}$ Calista, D. 1994. Policy Implementation. In Nagel, S. (ed.) Encyclopaedia of policy studies, pp.117-155. New
}

York: Marcel Dekker meliputi sandang, pangan, papan, tetapi juga pada kemudahan mengakses pelayanan publik seperti air bersih, transportasi, sanitasi, kesehatan, dan pendidikan. Hal tersebut sesuai dengan dokumen yang diterbitkan oleh ILO yang berjudul Growth and Basic Needs dimana Basic Needs adalah tema sentral dan unggulan untuk pembangunan dunia ke tiga (Suryono, 2010: 20). Penerapan pembangunan basic needs tersebut lebih cocok diterapkan di daerah pedesaan sehingga pendekatannya bukan central planing melainkan lebih bersifat community development.

Kesejahteraan sangat erat hubungannya dengan kemiskinan. Kemiskinan dalam arti luas dapat meliputi kemiskinan di bidang ekonomi, sosial, budaya, politik , iman dan akhlak (Suryono dan Noor 2016). Sen (1999:3) juga berpendapat bahwa pembangunan adalah sebuah proses kebebasan dimana semua orang berhak menikmatinya sehingga dengan pembangunan diharapkan akan terbebas dari kemiskinan dan keterbelakangan. Mubyarto dalam Daldjoeni(1998:88) mengatakan

"Membangun desa miskin berarti meningkatkan kemampuan rakyat dengan cara mengembangkan dan mendinamisasikan potensinya. Pembangunan tersebut dapat dilihat dari tiga sisi: Pertama menciptakan iklim yang memungkinkan potensi masyarakat berkembang. Kedua, memperkuat potensi ekonominya lewat peningkatan pendidikan, kesehatan, serta terbukanya kesempatan untuk memanfaatkan peluang-peluang ekonomi. Ketiga, mengembangkan ekonomi rakyat dan mencegah terjadinya persaingan yang tidak seimbang, serta mencegah eksploitasi golongan ekonomi yang kuat atas yang lemah. Upaya ini dalam rangka proses pemberdayaan pengembangan prakarsanya."

Beberapa bentuk pembangunan dapat memunculkan "inequalitity" diantara beberapa wilayah dan ada pula pembangunan lain yang digunakan untuk mengurangi "inequality" tersebut (Willis, 2000:8). Jangan sampai perencanaan yang dibuat oleh perencana memunculkan ada "missing people" yang tidak tersentuh pembangunan atau pembangunan yang diberikan tidak memberikan efek positif pada masyarakat misalkan pendapatan yang layak hanya diperoleh masyarakat tertentu. Adanya distribusi pendapatan yang menurut Suryono( 2010; 148) ) tidak merata ini dapat menyebabkan kemiskinan relatif. Chambers (1987) juga berpendapat bahwa kemiskinan muncul karena adanya proses interaksi dari berbagai faktor akibat dari situasi ketidakadilan, ketidakpastian, ketimpangan, ketergantungan dalam struktur masyarakat.

Untuk mendorong percepatan pengembangan kawasan yang berpotensi sebagai pusat pertumbuhan wilayah, serta untuk mendorong pertumbuhan daerah 
tertinggal dan perbatasan, maka Pemerintah Kabupaten Pacitan mengeluarkan kebijakan yang tertuang dalam Surat Keputusan Bupati Pacitan Nomor: 188.45/ 30. A /KPTS/ 408.21/2012 tentang Kawasan Strategis dan Cepat Tumbuh di Kabupaten Pacitan. Surat keputusan ini dijadikan dasar kebijakan daerah untuk melakukan kegiatan-kegiatan pembangunan yang ditujukan di kawasan yang telah ditetapkan. Untuk melaksanakan kebijakan yang diturunkan oleh Kepala Daerah, Bappeda sebagai lembaga perencana pembangunan seyogyanya merespon kebijakan Bupati tersebut kedalam sebuah perencanaan strategis yang termuat dalam sebuah dokumen perencanaan KSCT. Namun sayangnya hingga tahun 2016, ketersediaan dokumen yang memuat secara khusus dan terperinci tentang tujuan sasaran dan target yang hendak dicapai dalam kebijakan KSCT sebagai misal dokumen masterplan KSCT Kabupaten Pacitan belum tersedia. Sehingga pelaksanaan implementasi kebijakan KSCT terkesan tidak terarah.

Secara Administratif, Kabupaten Pacitan terdiri dari dua belas kecamatan yang meliputi Kecamata Donorojo, Kecamata Pringkuku, Kecamatan Punung, Kecamatan Pacitan, Kecamatan Kebonagung, Kecamatan Arjosari, Kecamatan Banda, Kecamatan Nawangan, Kecamatan Tegalombo, Kecamatan Tulakan, Kecamatan Ngadirojo, dan Kecamatan Sudimoro. Masyarakat yang tinggal dikabupaten ini sangat menggantungkan hidupnya pada sumber daya alam yang tersedia. Di daerah selatan masyarakat sangat menggantungkan hidupnya pada laut dan sawah. Sedangkan yang berada di daerah utara masyarakat menggantungkan hidup sebagai petani dan sektor perdagangan. Keberadaan sawah yang terus berkurang yang diakibatkan oleh beberapa macam bencana seperti tanah longsor dan kekeringan serta alih fungsi lahan sangat mempengaruhi kesejahteraan.

\section{METODE}

Penelitian ini menggunakan metode kualitatif dengan teknik yang digunakan adalah menggunakan observasi, depth interview, dokumen. Teknik purposive interview dipilih sebagai langkah awal untuk mendapat informasi yang selanjutnya dari informan akan ditunjukkan informan lainnya yang dapat menjelaskan peristiwa secara lebih mendalam dan menyeluruh. Lokasi penelitian adalah di Bappeda sebagai leading perencanaan kebijakan KSCT (Kawasan Strategis Cepat Tumbuh) dan merupakan instansi dimana dokumen terkait KSCT tersedia.Informan adalah kepala Bappeda, Kepala Bidang Analisa Data Perencanaan dan Pengendalian Pembangunan , Kepala Bidang Pembangunan Manusia dan Masyarakat, Kepala Bidang Ekonomi Sumber Daya Alam dan Infrastruktur.
Sedangkan untuk mengetahui bagaimana dampak dari sebuah kebijakan, dilakukan wawancara kepada pelaku usaha yang ada di pusat pertumbuhan agrpolitan dan pusat pertubumbuhan pariwisata. Pelaku usaha tersebut antara lain pengusaha minuman herbal, pengusaha dan petani tanaman janggelan. Sedangkan di pusat pertumbuhan kawasan pariwisata dilakukan wawancara kepada pemiliki warung, perental ATV, penyewa perahu.

\section{HASIL DAN PEMBAHASAN Hasil}

\section{Content Kebijakan KSCT}

Kebijakan KSCT diambil sebagai langkah atau upaya dan grand design untuk menumbuhkan pusat perekonomian baru di Kabupaten Pacitan dan mengurangi ketimpangan kesejahteraan yang terjadi di Kabupaten Pacitan. Dalam dokumen laporan pendahuluan Penyusunan Dokumen Pengembangan KSCT dinyatakan bahwa arah kebijakan dimaksudkan untuk mendukung pusat pertumbuhan antara lain:

Kebijakan Sosiokultural (Kawasan Pariwisata):

a. Pengembangan sistem keruangan wisata terpadu melalui pembentukan kawasan pengembangan pariwisata dengan tema-tema khusus;

b. Pengembangan fasilitas layanan wisata terpadu dalam rangka pembentukan simpul-simpul-simpul pusat pelayanan skala regional dan lokal;

c. Pengembangan produk kepariwisataan yang mengacu pada pendekatan koridor wisata terbatas lintas batas wilayah (borderless tourism).

Kebijakan daerah yang tertuang dalam dokumen pengembangan KSCT pada kawasan strategis ekonomi (Kawasan Agropolitan) adalah peningkatan pelayanan kebutuhan dasar untuk mendukung kegiatan pertanian, namun dengan prinsip utama yang mengarah pada pelestarian lingkungan hidup. Strategi yang dikembangkan untuk mendukung kebijakan kawasan strategis ekonomi adalah pengembangan potensi pertanian, dan industri yang mendukung pendekatan agrobisnis serta penyediaan infrastruktur yang memadai.

Sedangkan pada kawasan strategis tekhnologi tinggi kebijakan yang ada adalah pengembangan PLTU yang berada di Kecamatan Sudimoro. Kebijakan kawasan tekhnologi tinggi diarahkan untuk mengembangkan kegiatan-kegiatan di dalamnya dengan tetap menjaga kelestarian lingkungan. Namun pengembangan kawasan teknologi tinggi tidak menjadi fokus dalam penelitian ini. Dalam permendagi Nomor 29 tahun 2008 pasal 9 dinyatakan bahwa:

a. "Pelaku usaha baik skala mikro, kecil, menengah, dan besar merupakan pelaku utama pengembangan sektor riil di kawasan strategis cepat tumbuh di daerah; 
b. Pemerintah, pemerintah daerah provinsi, dan pemerintah daerah kabupaten/kota memfasilitasi kegiatan pelaku usaha sebagaimana dimaksud pada ayat (1)".

Sedangkan dari beberapa prinsip yang dapat dilihat dari Permendagri Nomor 29 tahun 2008 disebutkan:

a. "peningkatan keterkaitan bisnis yang saling menguntungkan antara pelaku usaha skala besar, dengan usaha mikro, kecil, dan menengah (UMKM) melalui pemberdayaan masyarakat UMKM;

b. keadilan di antara pelaku usaha di hulu dengan di hilir".

Jadi dari isi yang termuat dalam Permendagri tersebut dapat ditarik kesimpulan bahwa yang menjadi pelaku dalam pengembangan KSCT adalah pelaku usaha baik kecil, mikro dan menengah yang berada di kawasan agropolitan dan kawasan pariwisata dan pengusaha baik di hilir maupun di hulu . Peran pemerintah dalam hal pengembangan KSCT adalah sebagai fasilitator dan stabilitator yang dapat menjaga keadilan antar pelaku usaha. Pelaku usaha dalam penelitian ini adalah pelaku usaha yang ada di kawasan agropolitan dan di kawasan pengembangan pariwisata.

Setelah melihat beberapa aspek dari hasil analisaanalisa yang dilakukan maka dalam rencana induk pengembangan KSCT tahun 2015 dilakukan penataan alokasi ruang KSCT untuk mengoptimalkan pengelolaan ruang KSCT.

Dalam dokumen KSCT hasil analisa selanjutnya tentang pengembangan KSCT didapatkan pusat-pusat pengembangan industri:

a. Pusat industri terpadu : Kecamatan Pacitan

b. Kawasan Minapolitan : Kecamatan Ngadirojo

c. Industri Pengolahan dan Pemasaran: Kecamatan Ngadirojo, Tulakan

d. Kawasan Agropolitan : Titik-titik tersebut mencakup dua kecamatan yaitu Bandar dan Nawangan sebagai satu kesatuan fungsi kawasan agropolitan

e. Kawasan Ekowisata : Kecamatan Punung

\section{Conteks (Lingkungan) Kebijakan}

Telah dijelaskan diatas bahwa pelaksanaan KSCT di Kabupaten Pacitan pada awal pelaksanaannya mengacu pada dokumen RTRW Kabupaten Pacitan 2010-2028. Sehingga kebijakan-kebijakan terkait penataan ruang pada saat itu dipengaruhi oleh komitmen politis antara Kepala Daerah periode 2006-2011. Terpilihnya kepala negara yang berasal dari Pacitan kala itu juga turut memberikan pengaruh yang sangat besar terhadap perkembangan pembangunan yang ada di Kabupaetn Pacitan. Dengan masuknya Kabupaten Pacitan sebagai kawasan karst dan Geopark dunia turut mendorong perkembangan wisata pantai yang ada di Kabupaten Pacitan. Maka tidak heran pada dokumen RTRW perencanaan-perencanaan lebih banyak memuat perencanaan pada pengembangan pariwisata daripada pengembangan agropolitan yang berbasis pengembangan di sektor produksi pertanian. Di Kabupaten Pacitan urusan pertanian diselenggarakan oleh OPD-OPD yaitu Dinas Tanaman Pangan dan Peternakan (Distanak) serta Dinas Pangan. Dari segi perencanaan terkait KSCT, Bappeda Kabupaten Pacitan melaksanakan kebijakan terkait KSCT melakukan aksinya yang dibiayai dalam APBD melalui program Perencanaan Pengembangan Wilayah Strategis Cepat Tumbuh. Untuk mencapai program tersebut kegiatan yang dilaksanakan adalah Penyusunan Perencanaan Pengembangan Wilayah Srategis dan Cepat Tumbuh dan hasil yang didapatkan dari pelaksanaan kegiatan ini adalah dokumen perencanaan pengembangan wilayah strategis dan cepat tumbuh dan arahan clusterisasi kawasan industri.

Rencana induk yang memuat tentang kebijakan dan strategi pengelolaan potensi, masalah dan peluang pengembangan kawasan tersebut disusun ke dalam skenario arah kebijakan pengembangan kawasan dituangkan dalam laporan awal dan laporan akhir Penyusunan Dokumen Pengembangan Kawasan Strategis Cepat Tumbuh Kabupaten Pacitan . Adapun tujuan dalam penyusunan dokumen tersebut adalah untuk mendorong percepatan pertumbuhan dan perkembangan daerah atau kawasan yang berpotensi berdasarkan potensi unggulannya serta mengurangi kesenjangan dengan daerah lainnya sehingga terwujud keterpaduan, keseimbangan dan keserasian pertumbuhan antar wilayah

Dokumen perencanaan tersebut belum memiliki kekuatan hukum yang mana tidak ada keputusan bupati atau peraturan daerah sesuai aturan perundang-undangan sehigga untuk pelaksanaannya tidak bersifat memaksa dan bukan hal yang wajib dilaksanakan. Jika melihat kembali dari isi Permendagri Nomor 29 tahun 2008 pada Pasal 7 :

(1) Kawasan Strategis Cepat Tumbuh di daerah ditetapkan sesuai dengan peraturan perundang-undangan.

(2) Penetapan Kawasan Strategis Cepat Tumbuh di daerah sebagaimana dimaksud pada ayat (1), disampaikan kepada Menteri Dalam Negeri dengan tembusan Menteri/Pimpinan Lembaga Pemerintah Non Departemen terkait.

Dari Pasal (7) ayat 1 Permendagri Nomor 29 tahun 2008, Bappeda Kabupaten Pacitan telah mengusulkan kawasan-kawasan strategis yang menjadi 
pilihan untuk ditetapkan yaitu dengan keluarnya SK Bupati tentang KSCT Kabupaten Pacitan yang memuat tentang wilayah-wilayah KSCT di Kabupaten Pacitan. Untuk mendapatkan pendanaan KSCT , SK bupati tersebut telah dikirimkan kepada Menteri Dalam Negeri. Sehingga pasal 7 Permendagri Nomor 29 tahun 2008 telah secara adminstrasi dilaksanakan oleh Pemerintah Daerah Kabupaten Pacitan.

Rencana induk yang ada di Bappeda yaitu Rencana (RIPDA) 2016-2025 yang menjabarkan tentang rencana pariwisata karena hal ini merupakan tuntutan dari RIPNAS itu sendiri. Karena keterbatasan pendanaan yang tersedia maka pemerintah daerah mengambil kebijakan untuk memilih menyusun RIPDA terlebih dahulu daripada penyusunan Rencana induk KSCT itu sendiri. Karena RIPDA sendiri merupakan kebijakan pendukung KSCT, jadi kawasan strategis yang menjadi prioritas untuk dikembangkan yaitu kawasan strategis pariwisata sosiokultural (pariwisata) Kabupaten.

Sedangkan rencana pengusahaan yang disusun secara lima tahunan yang dimaksud dalam pasal 15 Permendagri Nomor 29 tahun 2008 belum dilakukan karena SK bupati tentang KSCT diterbitkan pada tahun 2012. Rencana pengusahaan hendaknya disusun kembali pada tahun 2017. Sedangkan yang dimaksud dengan rencana pengusahaan adalah rencana pengembangan sektor dan produk unggulan sebagai penggerak perekonomian di kawasan strategis provinsi/kabupaten/kota dalam kurun waktu lima tahunan sesuai dengan Rencana Induk, yang memuat proyeksi pengembangan hulu-hilir sektor dan produk unggulan, informasi dan akses pasar, akses permodalan, akses teknologi, aksesibilitas prasarana (infrastruktur) dan sarana pendukung transportasi dan distribusi, guna meningkatkan produk-produk yang berdaya saing di pasar lokal, pasar regional, pasar nasional dan pasar internasional.

Daya tanggap dapat ditunjukkan bagaimana pemahaman implementor dalam merumuskan tujuan di daerah untuk disinergiskan dengan tujuan induk KSCT yaitu Permendagri Nomor 29 Tahun 2008 tersebut. Tujuan yang termuat dalam pengembangan KSCT tersebut juga harus sejalan dengan tujuan pengembangan wilayah strategis yang ada dalam RTRW Kabupaten Pacitan.

\section{Pembahasan}

Outcomes merupakan hasil keluaran program sedangkan impact jangkauannya lebih luas lagi yaitu dampak yang dirasakan masyarakat atau kelompok sasaran akibat dari kebijakan yang diimplementasikan. Sehingga bentuk-bentuk program tersebutlah yang hasilnya akan diterima oleh penerima kebijakan. Hasil yang diperoleh di lapangan menunjukkan bahwa implementasi kebijakan sebagian besar dilakukan untuk pengembangan kawasan pariwisata saja. Sehingga impact atau dampak yang paling besar akan dirasakan oleh masyarakat yang ada di kawasan prioritas.

Content-content mengenai tujuan kebijakan KSCT sebenarnya hampir mirip dengan apa yang disampaikan dalam konsep perencanaan Al haq (1995). Namun konsep perencanaan KSCT belum mencakup beberapa elemen dari Al-Haq, hal ini nampak pada hasil empiris di lapangan (1) Belum terwujudnya keseimbangan yang menjadi neraca manusia (ketrampilan, distribusi pendapatan relatif dan kemiskinan ,pengangguran dan kesempatan kerja, distribusi antara kota dan desa, level pembangunan manusia, bagaimana budaya dan perilaku warga setempat, (2) Belum menjadikan kebutuhan dasar manusia sebagai target utama dalam perencanaan namun lebih memikirkan pembangunan fisik yang ditujukan untuk produksi dan konsumsi, (3) Belum ada kejelasan perencananaan pembangunan tentang bagaimana mendistribusikan hasil produksi dan kebijakan yang menjamin hasil produksi tersebut dapat terdistribusi, termasuk action programmes dan mekanisme pengiriman sehingga mendorong kaum miskin untuk berproduksi khususnya para petani cilik dan pengusaha kecil (4) Belum optimalnya strategi pembangunan manusia yang desentralisasi untuk melibatkan partisipasi masyarakat dan kemandirian; (5) Tidak ditemukannya Rencana pembangunan harus memuat human framework untuk menganalisa kinerjanya.

Dampak ketimpangan kesejahteraan yang terjadi tidak terlepas dari efek negatif dari prioritas pembangunan. Belum terwujudnya keseimbangan yang menjadi neraca manusia dapat disebabkan dari keinginan pemerintah dan target Bupati untuk meningkatkan PAD dan pertumbuhan ekonomi dan hal tersebut merupakan faktor yang ikut bertanggung jawab atas ketimpangan tersebut. Daerah yang mendapatkan prioritas pengembangan akan merasakan betul efek pengembangan tersebut. Sedangkan daerah yang belum berhasil berkembang tampaknya harus lebih bersabar, menanti giliran pengembangan selanjutnya.

Strategi pembangunan yang belum menjadikan kebutuhan dasar manusia sebagai target utama dalam perencanaan namun lebih memikirkan pembangunan fisik yang ditujukan untuk produksi dan konsumsi, tampak dalam Impact yang dirasakan oleh masyarakat. Kebijakan pengembangan kawasan dengan memilih desa yang dianggap sebagai penarik utama ternyata hanya membawa manfaat positif bagi sebagian penduduk saja, yang dalam tesis ini adalah penduduk yang tinggal di kawasan-kawasan pesisir. 
Dalam teori Tarigan (2004) menyebutkan bahwa Growth Pole (pusat pertumbuhan) memiliki dua cara yaitu secara fungsional dan geografis dan harus memiliki berbagai multiplier effect (unsur pengganda), nilai ekonomi, konsentri geografis, dan sifat mendorong pertumbuhan daerah sekitar. Jika secara fungsional pusat pertumbuhan berada pada posisi konsentris kelompok usaha atau cabang industri, sehingga mampu menstimulasi kehidupan ekonomi baik ke dalam maupun ke luar kawasan. Sedangkan pertumbuhan secara geografis, berarti pusat pertumbuhan tersebut memiliki fasilitas dan kemudahan yang dapat menarik berbagai usaha untuk berlokasi di daerah tersebut. Pusat pertumbuhan ini menurut penulis mirip seperti pola pada pusat pertumbuhan kawasan pantai desa Klayar yang dengan keindahan alam mampu menarik usaha-usaha lain berkembang di lokasi tersebut. Namun sejauh mana pengaruh keluar ini belum ada ukuran secara pasti.

Efek pembangunan tidak hanya dirasakan oleh warga Desa Sendang saja, namun mampu membawa efek yang positif bagi penduduk dari Desa Kalak Kecamatan Donorojo, dan Desa Dersono Kecamatan Pringkuku. Pusat KPP Punung pun turut mendapat manfaat dengan semakin ramainya pengunjung yang datang ke pantai Klayar. Di kota Kecamatan Punung yang letaknya strategis tersebut, dapat dijumpai beberapa toko atau kios-kios yang menjual makanan-makanan lokal seperti produk olahan ikan, dan makanan tradisional lainnya.

Dari Al Haq diatas tentang tidak ada kejelasan distribusi secara komprehesif dan terintegratif dalam konsep KSCT hal ini tampak pada kurangnya analisa konsep hulu dan hilir. Tidak berkembangnya hulu di agropolitan salah satu yang dapat dijadikan alasan adalah jauhnya jangkauan dan sulitnya mendapatkan pasar. Di kecamatan Arjosari, yang berbatasan langsung dengan kecamatan Nawangan terdapat potensi pasar (hilir) yang belum dikaji lebih dalam. Pasar ini adalah wisata banyuanget yang memiliki trend kunjungan wisatanya meningkat setiap tahun. Sehingga adanya pemikiran untuk memperhatikan aspek sistem lokal produksi sehingga mendorong kaum miskin untuk berproduksi khususnya para petani cilik dan pengusaha kecil juga patut dipertimbangkan dalam pengembangan kawasan KSCT disamping itu pemerintah harus memiliki kebijakan yang menjamin hasil produksi tersebut dapat terdistribusi yaitu dengan menyediakan dan memberikan fasilitas pasar.

Infrastruktur di agropolitan belum mampu menciptakan konektivitas antar wilayah, yang seharusnya didukung dengan keterpaduan visi misi OPD dan pelaku usaha yang ada di Kabupaten Pacitan. Seharusnya sektor pariwisata dan agropolitan memiliki keterpaduan dan saling mendukung, sehingga tidak berjalan secara parsial seperti yang terjadi sampai saat ini.Jika pelaksanaannya parsial,maka yang terjadi adalah ketimpangan dan ketidakseimbangan. Karena keseimbangan perencanaannya belum terwujud maka perencanaan dari segi holistik, tematik dan spasial, integratif juga tidak terwujud.

Desa Jeruk Kecamatan Bandar memang memiliki daya tarik bagi pedagang luar untuk datang mengambil komoditas bahan baku dari Bandar dan Nawangan. Namun Kawasan ini belum mampu memberikan mutiplier effect dan gaya dorong desa lainnya. Hal lemahnya gaya dorong ini karena sangat minimnya aktifitas produksi. Lemahnya produksi disebabkan belum tampak adanya upaya untuk memperjuangkan nilai tambah dan pengembangan kawasan agropolitan yang mengarah kepada human framework, namun lebih memfasilitasi pergerakan aliran barang mentah keluar kabupaten daripada mengolah dan menjual hasil produksi ke dalam kabupaten. Peningkatan nilai tambah komoditas unggulan Bandar Nawangan selama ini masih menjadi milik kabupaten lain dimana pengolahan minuman sari janggelan berada di Kabupaten Ponorogo.

Ketidakseimbangan yang terjadi antara pembangunan fisik dan SDM khususnya di kawasan agropolitan disebabkan karena perencanaan yang belum menjadikan kebutuhan dasar manusia sebagai target utama dalam perencanaan namun lebih memikirkan pembangunan fisik. Dimana saat ini masyarakat yang ada di kawasan agropolitan sangat membutuhkan inovasi, pelatihan dan peningkatan sumber daya manusia. Contoh impact yang terjadi di agropolitan adalah kurang difikirkannya konsep pengembangan SDM dalam inovasi dan kreatifitas atau minimnya pelatihan. Kurangnya aktifitas warga lokal pada kegiatan ekonomi menjadikan pembangunan fisik atau sarana jalan kurang bermanfaat untuk masyarakat lokal. Jalan tersebut justru lebih banyak menguntungkan para tengkulak dari luar yang akan mengangkut hasil bumi dari kawasan agropolitan.

Namun hasil penelitian sedikit berbeda dengan hasi implementasi kawasan agropolitan di Kabupaten Bangkalan yang dilakukan oleh Dhoni (2012). Pengembangan kawasan di Kabupaten Bangkalan tidak didukung dengan penyediaan infrastruktur yang baik. Sedangkan pengembangan kawasan agropolitan di Kabupaten Pacitan, dukungan infrastruktur jalan sudah mulai dilakukan pembenahan dan perbaikan. Hasil penelitian di lapangan diperoleh hasil jalan yang sudah bagus. Namun upaya penyediaan jalan kurang disertai dengan penyediaan pelatihan dan peningkatan kualitas SDM di kawasan agropolitan. Sedangakan akses permodalan bagi pelaku usaha di kawasan sudah tersedia seperti bank, dan bantuan permodalan dari pemerintah. 
Sehingga untuk mengembangkan suatu kawasan sektor-sektor harus mendukung. Sebaik apapun sarana dan prasarana juga tidak akan bermanfaat apabila yang menggunakan hanya sedikit atau jarang digunakan. Begitu pula sebaliknya, suatu daerah juga tidak bisa berjalan sesuai dengan fungsinya apabila infrastruktur juga tidak mendukung. Sebaik apapun kualitas manusianya tanpa ditunjang sarana juga akan sulit untuk mencapi tujuan yang diharapkan. Sehingga keterkaitan semua unsur mutlak diperlukan untuk mengembangkan suatu kawasan. Suatu kebijakan yang paling utama adalah ditujukan untuk manusia, jadi konsep human framework dan basic needs harus melekat pada perencanaan-perencanaan program pengembangan suatu kawasan.

\section{PENUTUP}

\section{Simpulan}

Hasil yang diperoleh tampak pada pembangunan yang pesat di Desa Sendang Kecamatan Donorojo, sehingga Impact bagi masyarakat di kawasan yang berhasil tumbuh adalah tersedianya peluang-peluang usaha baru dan kelompok-kelompok usaha binaan pemerintah di sektor pariwisata. Dampak negatif dari kebijakan KSCT ini adalah belum mampu mengurangi tingkat kesenjangan antara kawasan utara dan selatan yang terjadi akibat kawasan di utara tidak masuk dalam kebijakan prioritas baik daerah maupun nasional.

\section{Saran}

Diperlukan adanya kejelasan perencanaan distribusi secara komprehesif tentang kejelasan sistem hulu dan hilir dan terintegratif (kesatuan tiga kawasan) dalam konsep KSCT yang mengakomodir seluruh kepentingan dan produk unggulan yang ada di tiga kawasan tersebut.

\section{DAFTAR PUSTAKA}

Daldjoeni, N. 1987.Geografi Kota dan Desa.Bandung: PT alumni

1997. Geografi Baru (Organisasi

keruangan Dalam teori dan Praktek). Bandung:

Alumni

Dye, Thomas R.19881. Understanding Public Policy, Prentice-Hall, New Jersey

Grindle, S. Merilee. 1980. Politics and Policy Implementation in The Third Wolrld. New Jersey : Princeton University Press.
Suryono, Agus. 2010. Dimensi-Dimensi Prima Teori Pembangunan. Malang: Universitas Brawijaya Press (UB Press).

Suryono, Agus, Noor, Tauchid. 2010. Teori-Teori Sosial. Malang: Universitas Negeri Malang

Tarigan, Robinson. 2004. Perencanaan Pembangunan Wilayah. Jakarta: Bumi Aksara

Willis, Katie. 2005. Theories and Practices of Development. New York: Taylor \& Francis e-Library. 